\title{
Properties of Apricot Kernel and Oils as Fruit Juice Processing Waste
}

\author{
Mehmet Musa Özcan ${ }^{1}$, Cundullah Özalp ${ }^{2}$, Ahmet Ünver ${ }^{1}$, Derya Arslan ${ }^{1}$, Nesim Dursun ${ }^{3}$ \\ ${ }^{1}$ Department of Food Engineering, Faculty of Agriculture, University of Selçuk, Konya, Turkey; ${ }^{2}$ Food Engineering, Malatya, Turkey; \\ ${ }^{3}$ Department of Soil Science, Faculty of Agriculture, University of Selçuk, Konya, Turkey. \\ Email: mozcan@selcuk.edu.tr
}

Received April 26 $6^{\text {th }}, 2010$; revised July $12^{\text {th }}, 2010$; accepted July $20^{\text {th }}, 2010$.

\begin{abstract}
Recently, more attention has been focused on the utilization of food processing by products and wastes, as well as under-utilization agricultural products. Some physical and chemical properties, mineral contents and fatty acid composition of apricot kernel and oils were determined. The oil yields from kernels changed from 42.2\% to 57.2\%. The crude fibre contents ranged between $4.06 \%$ and $7.63 \%$. In addition, crude protein contents ranged between $15.1 \%$ and $24.2 \%$. While the peroxide values of kernel oils change between $0.834 \mathrm{meq} / \mathrm{Kg}$ and $8.294 \mathrm{meq} / \mathrm{Kg}$, acidity values ranged between $0.279 \%$ and $0.700 \%$. The main fatty acids in apricot kernel oils were oleic, linoleic and palmitic acids. Oleic acid contents of kernel oils varied between $53.06 \%$ and $70.90 \%$. On the other hand, linoleic acid contents ranged between $21.43 \%$ and 35,67\%. As a result, the present study showed the apricot kernels of the researched species of apricot kernels from Turkey are a potential source of valuable oil which might be used for edible and other industrial applications.
\end{abstract}

Keywords: Apricot, Kernel, Oil, Fatty acid Composition, Mineral Contents

\section{Introduction}

Apricot (Prunus armeniaca L.) is a member of the Rosaceae family and is widely distributed in most countries of the world. The problems of industrial waste are becoming harder to solve, and much effort will be needed to develop the nutritional and industrial potential of by-products [1]. The kernels are considered as nontraditional potential resources for oils [2-3]. World apricot production is about 2.5 million ton. Turkey produces about $1 / 5$ of total world apricot production. The apricot production in Turkey is 557.572 ton and 716.415 ton in 2007 and 2008 years, respectively. The one of highest apricot growing location in Turkey is Malatya province [4]. Some fruit seeds such as cherry, apricot, citrus and apple can be used as sources of oils. Some seed oils are already used for several purposes: blending with highly saturated edible oils to provide new oils with modified nutritional values as ingredients in paint and varnish formulations, surface coatings and oleo-chemicals, and as oils for cosmetic purposes [5]. Currently, large amounts of fruit seeds are discarded yearly at processing plants. This not only wastes a potentially valuable resource but also aggravates an already serious disposal problem. To be economically viable, however, both oil and meal from these fruits seeds must be utilized [6].
The aim of this study was to determine their physical and chemical properties of apricot kernel contents of several apricot cultivars collected from Malatya province in Turkey.

\section{Material and Method}

\subsection{Material}

Apricot cultivar (Hüdayi, Hacıhaliloğlu, Soğanc1, Şahinbey, Hacıkız, Canino, Caona, Sakıt-2, Çekirge-52, Erkenağerik, 693-K, Karacabey, Ethembey, Alyanak, Kabaaşı, Hasanbey and Aprikoz) kernels were obtained by hand processing from apricots growing in Malatya province of Turkey in August 2008. Kernels were kept in glass jars until analyses at refrigerator. In all stages of trials, dry and mature kernels have been used.

\subsection{Chemical Analyses}

The some chemical compositions (crude fiber, crude oil, crude protein and crude ash) were analyses according to AOAC [7]. Viscosity values of kernel oils were measurement with Vibro (SV-10) Viscosimetry [7]. For oil analyses, each samples was homogenized and subjected to extraction for $6 \mathrm{~h}$ with petroleum ether (boiling range $30-60^{\circ} \mathrm{C}$ ) in a Soxhlet apparatus. The extracted oil was 
dried over anhydrous sodium sulphate and the solvent was removed under reduced pressure in a rotary film evaporator. Oil percentages were determined by weight difference. Ash was determined in a muffle furnace at $900^{\circ} \mathrm{C}$ for $8 \mathrm{~h}$ [7]. The nitrogen content estimated by the Kjeldahl method and was converted to protein content by using the conversion factor 6.25 . The fiber and moisture were determined according to Demir and Özcan [8].

\subsection{Determination of Fatty Acids}

Fatty acid composition for apricot kernel samples were determined using a modified fatty acid methyl ester method as described by Hış1 [9]. The oil was extracted three times for $2 \mathrm{~g}$ air-dried seed sample by homogenization with petrolium ether. The oil samples $(50-100 \mathrm{mg}$ ) was converted to its fatty acid methyl esters (FAME). The methyl esters esters of the fatty acids $(1 \mu l)$ were analysed in a gas chromotography (Shimadzu GC-2010) equipped with a flame ionising detrctor (FID), a fused silica capillary column $(60 \mathrm{~m} \times 0.25 \mathrm{~mm}$ i.d.; film thickness 0.20 mikrometer). It was operated under the following conditions: oven temperature program. $90^{\circ} \mathrm{C}$ for 7 min. Raised to $240^{\circ} \mathrm{C}$ at a rate $5^{\circ} \mathrm{C} / \mathrm{min}$ and than kept at $240{ }^{\circ} \mathrm{C}$ for $15 \mathrm{~min}$ ); injector and detector temperatures, 260 and $260^{\circ} \mathrm{C}$; respectively, carrier gas. nitrogen at flow rate of $1.51 \mathrm{ml} / \mathrm{min}$; split ratio. $1 / 50 \mu \mathrm{l} / \mathrm{min}$.

A Standard fatty acid methyl ester mixture (Sigma Chemical Co.) was used to identify sample peaks. Commercial mixtures of fatty acid methyl esters were used as reference data for the relative retention times [10]. Quantitative analyses of the fatty acids were performed using the heptadecanoic acid methyl ester as internal Standard. The results are mean values of three replicates.

\subsection{Determiation of Mineral Contents}

About $0.5 \mathrm{~g}$ of dried and apricot kernels were put into burnig cup with $15 \mathrm{ml}$ of pure $\mathrm{NHO}_{3}$. The sample was incinerated in a MARS 5 microwave oven (CEM corporation Manufactura) at $200^{\circ} \mathrm{C}$. Distilled deionized water and ultrahigh-purity commercial acids were used to prepare all reagents, standards and apricot kernel samples. After digestion treatment. samples were filtrated through whatman No 42. The filtrates were collected in $50 \mathrm{ml}$ Erlenmayer flasks and analysed by ICP-AES (Varian). The mineral contents of the samples were quantified against standard solutions of known concantrations which were aralyjed concurrently [11].

\section{Working conditions of ICP-AES: Instrument \\ RF Power \\ Plasma gas flow rate $(\mathrm{Ar})$}

$\begin{array}{ll} & 15 “ \text { (axial) } \\ \text { Auxilary gas flow rate (Ar) } & : 1.5^{“} \\ \text { Viewing height } & : 5-12 \mathrm{~mm} \\ \text { Copy and reading time } & : 1-5 \mathrm{~s}(\max .60 \mathrm{~s}) \\ \text { Copy time } & : 3 \mathrm{~s}(\max .100 \mathrm{~s})\end{array}$

\subsection{Statistical Analyses}

Results of the research were analysed for statistical significance by analysis of variance [12]. This research was performed by three duplicates with a replicate.

\section{Results and Discussion}

The physical and chemical properties of some apricot kernels collected from Malatya province in Turkey are given in Table 1. The crude fibre, crude ash, crude protein, crude oil and kernel weigh values of apricot kernels were determined. According to variance analyses, important differences were found between crude cellulose, crude fibre, crude ash, crude protein, crude oil and their weighs and kinds as statistical, $\mathrm{p}<0,01$ level.

The oil yields of kernels varied from $42.2 \%$ (Canino cv) to $57.2 \%$ (Sakit-2 cv) of the dry weight. The oil contents of kernels changed among the varieties to more than about $50 \%$ of each. However, because of economical value of the oil, these kernels could be used as potential sources of oils. Sak1t-2 cultivar had the highest oil content, followed by Çekirge- $52 \mathrm{cv}(54.4 \%)$, Erkeneğerik-cv (54.7\%), Şahinbey cv (54.1\%), Ethembey cv (53.9\%), Kabaşı cv (53.9\%), Hacıkız cv (53.5\%) and Hac1haliloğlu $\mathrm{cv}(52.7 \%)$. The crude fibre contents ranged between $4.06 \%$ (Sakit-2 cv) and 7.63\% (Aprikoz). While crude ash contents change between $2.138 \%$ (Kabaaşı cv) and $3.454 \%$ (Aprikoz), crude proteins of kernels ranged between $15.1 \%$ (Kabaaş1 cv) to $24.2 \%$ (Caona cv). In addition, kernel weights changed between $0,300 \mathrm{~g} / \mathrm{unit}$ and $0,576 \mathrm{~g} / \mathrm{unit}$ (Alyanak cv), Femenia et al. [1] had reported that kernels of bitter and sweet apricots collected from Mallorca (Spain) contained oil between $39.7 \%$ and $47.2 \% ; 49.8 \%$ and $56.1 \%$ oil, respectively, In other study, kernel oil contents of almond were determined between $45.9 \%$ and $61.7 \%$ [13]. Dry kernels of plum, apricot and peach contained $32 \%, 37 \%$ and $43 \%$ of oil, respectively [3]. Kappor et al. [14] obtained values of up to $67 \mathrm{~g} / 100 \mathrm{~g}$ for oil content in sweet apricot varieties. Özcan [15] determined moisture (4,91-5.12\%), crude oil (45.3-51.4\%), crude protein (23.58-27.70\%), crude fibre (13.49-17.98\%), crude ash (2.10-2.67\%) and mass of 100 kernels (28.72-49.6 g) values of four apricot cultivars. These properties are effected mainly by variety [16]. However, higher protein contents $(37-45 \mathrm{~g} / 100 \mathrm{~g})$ have been reported by several authors $[6,16]$. The results in this work are in general agreement with these results. 
Our results related to apricot (47.55 to 55.45\%) was found similar values those of Kappor et al. [14], Femenia et al. [1], Özcan [15] and Matthaus and Özcan [17].

Some chemical and physical properties of kernel and oils are shown in Table 2 . According to variance analyses, differences between varieties to peroxide value, acidity, refractive index and viscosity were found statistically important at the $\mathrm{p}<0,01$ level. While the peroxide values of kernel oils change between 0.834 (Soğanc1) and $8.294 \mathrm{meq} / \mathrm{Kg}$ (Karacabey $\mathrm{cv}$ ), acidity values ranged between 0,279\% (Kabaaş1 cv) and 0,700\% (Karacabey). The highest peroxide values were established in Hasan-

Table 1. Physical and chemical properties of apricot kernel.

\begin{tabular}{cccccc}
\hline Cultivars & Crude fibre (\%) & Crude ash (\%) & Crude protein (\%) & Crude oil (\%) & Kernel weight (g) \\
\hline Hüdayi & $5.221 \mathrm{~cd}$ & $2.261 \mathrm{ef}$ & $19.172 \mathrm{bc}$ & $50.550 \mathrm{defg}$ & $0.471 \mathrm{ef}$ \\
Hacihaliloğlu & $4.459 \mathrm{fgh}$ & $2.500 \mathrm{bcde}$ & $17.342 \mathrm{cde}$ & $52.710 \mathrm{bcde}$ & $0.503 \mathrm{de}$ \\
Soğanc1 & $4.714 \mathrm{def}$ & $2.447 \mathrm{bcde}$ & $17.932 \mathrm{bcde}$ & $51.975 \mathrm{bcde}$ & $0.457 \mathrm{fg}$ \\
Sahinbey & $4.159 \mathrm{fgh}$ & $2.510 \mathrm{bcde}$ & $20.278 \mathrm{bc}$ & $54.110 \mathrm{abc}$ & $0.569 \mathrm{a}$ \\
Hacıkız & $4.638 \mathrm{efg}$ & $2.808 \mathrm{ab}$ & $18.126 \mathrm{bcd}$ & $53.470 \mathrm{bcd}$ & $0.552 \mathrm{ab}$ \\
Canino & $6.928 \mathrm{a}$ & $2.761 \mathrm{bc}$ & $18.001 \mathrm{bcde}$ & $42.195 \mathrm{1}$ & $0.359 \mathrm{~h}$ \\
Caona & $4.068 \mathrm{gh}$ & $2.310 \mathrm{def}$ & $24.201 \mathrm{a}$ & $49.840 \mathrm{efgh}$ & $0.425 \mathrm{~g}$ \\
Sakıt-2 & $4.060 \mathrm{~h}$ & $2.577 \mathrm{bcde}$ & $14.948 \mathrm{bc}$ & $57.185 \mathrm{a}$ & $0.545 \mathrm{abc}$ \\
Çekirge-52 & $5.099 \mathrm{cde}$ & $2.766 \mathrm{bc}$ & $19.265 \mathrm{bc}$ & $54.370 \mathrm{ab}$ & $0.554 \mathrm{ab}$ \\
Erkenağerik & $4.681 \mathrm{def}$ & $2.763 \mathrm{bc}$ & $15.980 \mathrm{de}$ & $54.735 \mathrm{ab}$ & $0.521 \mathrm{bcd}$ \\
693-K & $5.437 \mathrm{bc}$ & $2.747 \mathrm{bcd}$ & $17.403 \mathrm{cde}$ & $47.545 \mathrm{gh}$ & $0.566 \mathrm{a}$ \\
Karacabey & $4.426 \mathrm{fgh}$ & $2.358 \mathrm{bcde}$ & $20.589 \mathrm{ab}$ & $51 \mathrm{cdef}$ & $0.552 \mathrm{ab}$ \\
Ethembey & $5.371 \mathrm{c}$ & $2.707 \mathrm{bcd}$ & $19.215 \mathrm{bc}$ & $53.915 \mathrm{abc}$ & $0.511 \mathrm{~cd}$ \\
Alyanak & $4.195 \mathrm{fgh}$ & $2.455 \mathrm{bcde}$ & $17.573 \mathrm{cde}$ & $48.300 \mathrm{fgh}$ & $0.576 \mathrm{a}$ \\
Kabaaş1 & $6.027 \mathrm{~b}$ & $2.138 \mathrm{e}$ & $15.106 \mathrm{e}$ & $53.895 \mathrm{abc}$ & $0.487 \mathrm{def}$ \\
Hasanbey & $5.165 \mathrm{cde}$ & $2.789 \mathrm{bc}$ & $18.632 \mathrm{bcd}$ & $50.370 \mathrm{defg}$ & $0.568 \mathrm{a}$ \\
Aprikoz & $7.638 \mathrm{a}$ & $3.454 \mathrm{a}$ & $20.879 \mathrm{ab}$ & $47.170 \mathrm{~h}$ & 0.3001 \\
\hline
\end{tabular}

Table 2. Physical and chemical properties of apricot kernel oils.

\begin{tabular}{|c|c|c|c|c|}
\hline Cultivars & Peroxide value (meq/Kg) & Acidity (\%) & Refractive index $\left(\mathrm{n}^{20}{ }_{\mathrm{D}}\right)$ & Viscosity (Mpa) \\
\hline Hüdayi & $1.907 \mathrm{bc}$ & $0.641 \mathrm{bd}$ & $1.543 \mathrm{bc}$ & $40.300 \mathrm{a}$ \\
\hline Hacıhaliloğlu & $1.026 \mathrm{def}$ & $0.474 \mathrm{ef}$ & $1.535 \mathrm{ef}$ & $24.500 \mathrm{~h}$ \\
\hline Soğanc1 & $0.834 \mathrm{f}$ & $1.562 \mathrm{a}$ & $1.538 \mathrm{de}$ & $23.300 \mathrm{k}$ \\
\hline Şahinbey & $1.888 \mathrm{bc}$ & $0.416 f$ & $1.530 \mathrm{gh}$ & $26.350 \mathrm{n}$ \\
\hline Hacıkız & $0.932 \mathrm{ef}$ & $0.696 \mathrm{~b}$ & $1.542 \mathrm{bcd}$ & $27.350 \mathrm{f}$ \\
\hline Canino & $0.833 \mathrm{f}$ & $0.474 \mathrm{ef}$ & $1.546 \mathrm{ab}$ & $34.700 \mathrm{c}$ \\
\hline Caona & $1.235 \mathrm{def}$ & $0.447 \mathrm{ef}$ & $1.543 \mathrm{bc}$ & $29.350 \mathrm{e}$ \\
\hline Sakit-2 & $1.422 \mathrm{cde}$ & $0.306 \mathrm{ef}$ & $1.545 \mathrm{ab}$ & $16.250 \mathrm{n}$ \\
\hline Çekirge-52 & $0.986 \mathrm{def}$ & $0.615 \mathrm{bcd}$ & $1.533 \mathrm{fg}$ & $23.575 \mathrm{k}$ \\
\hline Erkenağerik & $2.210 \mathrm{~b}$ & $0.609 \mathrm{bcd}$ & $1.543 \mathrm{bc}$ & $14.550 \mathrm{o}$ \\
\hline $693-\mathrm{K}$ & $1.339 \mathrm{def}$ & $0.528 \mathrm{de}$ & $1.549 \mathrm{a}$ & $13.600 \mathrm{p}$ \\
\hline Karacabey & $8.294 \mathrm{a}$ & $0.700 \mathrm{~b}$ & $1.545 \mathrm{ab}$ & $25.900 \mathrm{~g}$ \\
\hline Ethembey & $1.199 \mathrm{def}$ & $0.446 \mathrm{ef}$ & $1.543 \mathrm{~b}$ & $31.150 \mathrm{~d}$ \\
\hline Alyanak & $1.267 \mathrm{def}$ & $0.584 \mathrm{~cd}$ & $1.539 \mathrm{~cd}$ & $17.550 \mathrm{~m}$ \\
\hline Kabaaşı & $1.481 \mathrm{~cd}$ & $0.279 \mathrm{ef}$ & $1.527 \mathrm{~h}$ & $35.200 \mathrm{~b}$ \\
\hline Hasanbey & $7.673 a$ & $0.444 \mathrm{ef}$ & $1.535 \mathrm{ef}$ & 21.1001 \\
\hline Aprikoz & $1.384 \mathrm{cde}$ & $0.639 \mathrm{bc}$ & $1.538 \mathrm{de}$ & 23.851 \\
\hline
\end{tabular}


bey cv $(7,673 \mathrm{meq} / \mathrm{Kg})$ and Karacabey cv $(8,294 \mathrm{meq} / \mathrm{Kg})$ samples. Refractive index was determined between 1.527 (Kabaaşı) and 1,549 (693-K cv). In addition, viscosity values of kernel oils were measured between 13,600 (693-K cv) and 40,300 (Hüdayi cv). Generally, the highest viscosity values were established in Hüdai, Canino, Kabaaşı and Ethem Bey cultivars. Differences among the values of Prunus varieties can probably be because of growing conditions, climatic, environmental conditions and analytic conditions.

Fatty acid composition of apricot kernel oils is given in Table 3. Results showed that the oils of all varieties used in this experiment had higher oleic acid content (between $53,06 \%$ and $70,90 \%$ ) than those of other fatty acids. On

Table 3. Mineral contents of apricot kernels (mg/Kg).

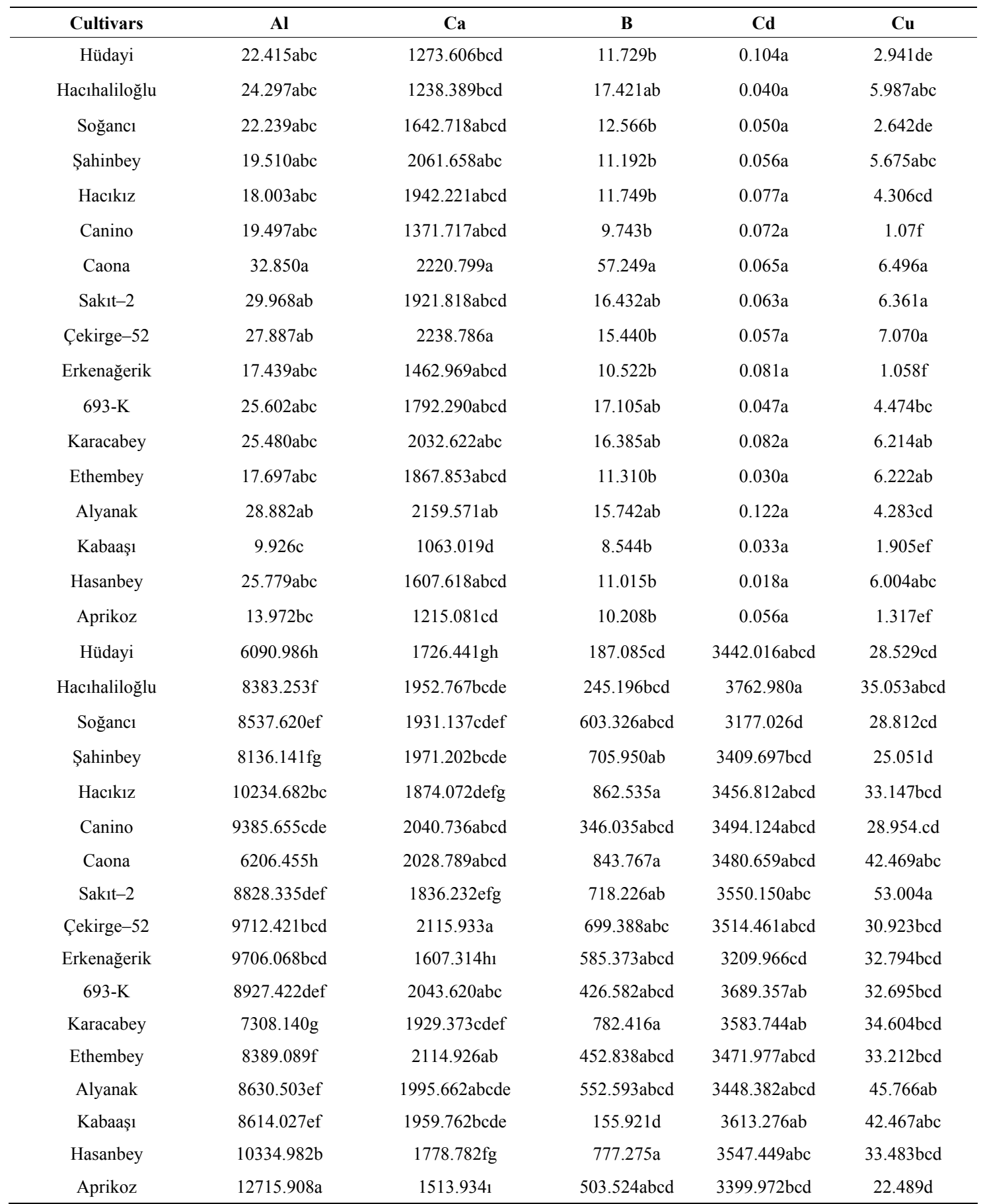


the other hand, linoleic acid contents of kernel oils ranged between 21.43\% (Sak1t-2 cv) and 35.67\% (Aprikoz cv), As an be observed, the proportions of the most abundant fatty acids (oleic acid) of the kernel oils varied among different varieties. This proportion was also higher than that in other fruit seed oils; mahaleb $(35,4 \%)$, cherry laurel $(53,7 \%)$, peanut $(56,27 \%)$, date pit $(49,54 \%)$, walnut $(13,8-33,0 \%)$ [18-21]. Palmitic acid is the main saturated component in all apricot cultivars. Palmitic acid is differed in the different apricot cultivars. Its percentage was found between 4,56\% (Caona cv) and 6,03\% (Aprikoz cv). The high concentration of linoleic acid in apricot kernel oils make these oils have high nutritional value as linoleic acid is one of the three essential fatty acids [11]. These results are in good agreement with in fatty acid composition for several Prunus kernels [1,3,15,17,20,22]. Matthaus and Özcan [17] determined from $43.9 \%$ to $78.5 \%$ oleic, from $9.7 \%$ to $37.0 \%$ linoleic and from $4.9 \%$ to $7.3 \%$ palmitic acids in some Prunus cultivars.

The ability of some unsaturated vegetable oils to reduce the serum cholesterol level may focus attention on the apricot kernel oil due to its high unsaturated oil content [1]. Our results are similar in fatty acid composition when compared to the values in the literature.

The mineral contents of apple kernels were determined by ICP-AES. The mineral compositions of kernels are summarized in Table 4. Mineral elements were found to vary widely depending on different apricot cultivar kernels. According to variance analyses, dif- ferences between apricot cultivars to $\mathrm{Cu}, \mathrm{K}$ and $\mathrm{Mg}$ were found statistically important at $\mathrm{p}<0,01$ level. Also, differences of cultivars had important at the $\mathrm{p}<$ 0,05 on $\mathrm{Zn}$ element.

$\mathrm{Ca}, \mathrm{K}, \mathrm{Mg}, \mathrm{Na}$ and $\mathrm{P}$ contents of all the apricot cultivar kernels were generally found very high. In addition, other minerals were determined very low. The levels of $\mathrm{Ca}$ of samples ranged between $1063.0 \mathrm{mg} / \mathrm{Kg}$ (Kabaaşı cv) and $2238.8 \mathrm{mg} / \mathrm{Kg}$ (Çekirge-52 cv), $\mathrm{K}$ contents were determined between $6206.5 \mathrm{mg} / \mathrm{Kg}$ (Caona cv) and 12715.9 $\mathrm{mg} / \mathrm{Kg}$ (Aprikoz). While Mg contents are established between $1513.9 \mathrm{mg} / \mathrm{Kg}$ (Aprikoz cv) and $2115.9 \mathrm{mg} / \mathrm{Kg}$ (Çekirge-52 cv), P contents of kernels were found between $3177.0 \mathrm{mg} / \mathrm{Kg}$ (Soğanc1 cv) and $3762.9 \mathrm{mg} / \mathrm{Kg}$ (Hac1haliloğlu cv). According to report of Femenia et al. [1], phosphorus, magnesium and calcium amounts ranged between 1100-1200 mg/100 gin apricot kernels. Also, the other essential elements; iron, manganese, copper, and zinc, account for 7-9,5 mg/100 g [1]. Average mineral contents of apricot varieties were found to be between $2.73-3.68 \%$ for $\mathrm{Na}, 1.06-2.94 \mathrm{ppm}$ for $\mathrm{P}, 0.35-0.64 \mathrm{ppm}$ for $\mathrm{K}$, 0.08-0.11 ppm for $\mathrm{Ca}, 0.23-0.26 \mathrm{ppm}$ for $\mathrm{Mg}, 10.7-74.9$ ppm for Fe, 11.80-42.35 ppm for $\mathrm{Zn}, 0.73-1.46 \mathrm{ppm}$ for $\mathrm{Mn}$ and 1.10-4.76 ppm for $\mathrm{Cu}$ [15].

These differencies of cultivars minerals may be due to growth conditions, varieties, genetic factors, harvesting time, soil properties, geographical variations and analytical procedures [23,24]. Calcium is the major component of bone and assists in teeth development [25]. Other elements

Table 4. Fatty acid composition of apricot kernel oils (\%).

\begin{tabular}{lccccc}
\hline \multicolumn{1}{c}{ Cultivars } & $\mathbf{K}$ & $\mathbf{M g}$ & $\mathbf{N a}$ & $\mathbf{P}$ & $\mathbf{Z n}$ \\
\hline Hüdayi & $6090.986 \mathrm{~h}$ & $1726.441 \mathrm{gh}$ & $187.085 \mathrm{~cd}$ & $3442.016 \mathrm{abcd}$ & $28.529 \mathrm{~cd}$ \\
Hacıhaliloğlu & $8383.253 \mathrm{f}$ & $1952.767 \mathrm{bcde}$ & $245.196 \mathrm{bcd}$ & $3762.980 \mathrm{a}$ & $35.053 \mathrm{abcd}$ \\
Soğanc1 & $8537.620 \mathrm{ef}$ & $1931.137 \mathrm{cdef}$ & $603.326 \mathrm{abcd}$ & $3177.026 \mathrm{~d}$ & $28.812 \mathrm{~cd}$ \\
Şahinbey & $8136.141 \mathrm{fg}$ & $1971.202 \mathrm{bcde}$ & $705.950 \mathrm{ab}$ & $3409.697 \mathrm{bcd}$ & $25.051 \mathrm{~d}$ \\
Hacıkız & $10234.682 \mathrm{bc}$ & $1874.072 \mathrm{defg}$ & $862.535 \mathrm{a}$ & $3456.812 \mathrm{abcd}$ & $33.147 \mathrm{bcd}$ \\
Canino & $9385.655 \mathrm{cde}$ & $2040.736 \mathrm{abcd}$ & $346.035 \mathrm{abcd}$ & $3494.124 \mathrm{abcd}$ & $28.954 . \mathrm{cd}$ \\
Caona & $6206.455 \mathrm{~h}$ & $2028.789 \mathrm{abcd}$ & $843.767 \mathrm{a}$ & $3480.659 \mathrm{abcd}$ & $42.469 \mathrm{abc}$ \\
Sakıt-2 & $8828.335 \mathrm{def}$ & $1836.232 \mathrm{efg}$ & $718.226 \mathrm{ab}$ & $3550.150 \mathrm{abc}$ & $53.004 \mathrm{a}$ \\
Çekirge-52 & $9712.421 \mathrm{bcd}$ & $2115.933 \mathrm{a}$ & $699.388 \mathrm{abc}$ & $3514.461 \mathrm{abcd}$ & $30.923 \mathrm{bcd}$ \\
Erkenağerik & $9706.068 \mathrm{bcd}$ & $1607.314 \mathrm{~h} 1$ & $585.373 \mathrm{abcd}$ & $3209.966 \mathrm{~cd}$ & $32.794 \mathrm{bcd}$ \\
693-K & $8927.422 \mathrm{def}$ & $2043.620 \mathrm{abc}$ & $426.582 \mathrm{abcd}$ & $3689.357 \mathrm{ab}$ & $32.695 \mathrm{bcd}$ \\
Karacabey & $7308.140 \mathrm{~g}$ & $1929.373 \mathrm{cdef}$ & $782.416 \mathrm{a}$ & $3583.744 \mathrm{ab}$ & $34.604 \mathrm{bcd}$ \\
Ethembey & $8389.089 \mathrm{f}$ & $2114.926 \mathrm{ab}$ & $452.838 \mathrm{abcd}$ & $3471.977 \mathrm{abcd}$ & $33.212 \mathrm{bcd}$ \\
Alyanak & $8630.503 \mathrm{ef}$ & $1995.662 \mathrm{abcde}$ & $552.593 \mathrm{abcd}$ & $3448.382 \mathrm{abcd}$ & $45.766 \mathrm{ab}$ \\
Kabaaş1 & $8614.027 \mathrm{ef}$ & $1959.762 \mathrm{bcde}$ & $155.921 \mathrm{~d}$ & $3613.276 \mathrm{ab}$ & $42.467 \mathrm{abc}$ \\
Hasanbey & $10334.982 \mathrm{~b}$ & $1778.782 \mathrm{fg}$ & $777.275 \mathrm{a}$ & $3547.449 \mathrm{abc}$ & $33.483 \mathrm{bcd}$ \\
Aprikoz & $12715.908 \mathrm{a}$ & 1513.9341 & $503.524 \mathrm{abcd}$ & $3399.972 \mathrm{bcd}$ & $22.489 \mathrm{~d}$ \\
\hline
\end{tabular}


which may contribute to biological processes, but which have not been established as essential, are barium, cadmium [23]. The high quantity of potassium, phosphorus, magnesium, and calcium, together with the small proportion of sodium plus the content of the essential elements as iron, manganese, copper, and zinc and allows the apricot, as well as the almond, to be considered as an excellent source of bioelements [26].

\section{Conclusions}

The accurate quantification of these analyses has very important applications for the nutrition sciences, because fatty acids, protein, oil and mineral contents in particular seed have a very important effect on health. These results of the experiment presented have shown that apricot cultivars have some distinctive chemical and physical properties, fatty acid and mineral content profiles. Kernels in apricot varieties can be a good source oil due to their abundance in the kernels and their high oil content. Such utilization of apricot fruits processing wastes could provide extra income and at the same time help minimize a waste disposal problem. The mineral contents of apricot cultivar kernels collected from Malatya province of Turkey were established by ICP-AES. The contents of most minerals such as $\mathrm{Ca}, \mathrm{K}, \mathrm{Mg}$ and $\mathrm{P}$ are at adequate levels. Mineral elements were found to vary widely depending on different apricot kernels. Apricot kernels were found to be important sources of nutrients and essential elements. In addition, it is apparent that apricot kernels are good sources of micro-and macro minerals, and consumed as a food ingredient to provide the human nutrient.

\section{Acknowledgements}

This work was supported by Selçuk University Scientific Research Project (S.U.-BAP, Konya-Turkey).

\section{REFERENCES}

[1] A. Femenia, Y. C. Chen, A. Mulet and J. Canellas, "Chemical Composition of Bitter and Sweet Apricot Kernels," Journal of Agricultural and Food Chemistry, Vol. 43, No. 2, 1995, pp. 356-361.

[2] R. Banerjee and V. V. R. Subrahmanyam, "Composition and Characteristics of a Few Potential Oils," ISF-OTAI Congress, 17th World Congress of the International Society for Fat Research, New Delhi, 18-19 February 1985.

[3] M. M. Hassanein, "Studies on Non-Traditional Oils: I. Detailed Studies on Different Lipid Profiles of Some Rosaceae Kernel Oils," Grasas y Aceites, Vol. 50, No. 85, 1999, pp. 379-384

[4] Anonymous, 2009. www.tuik.gov.tr

[5] H. E. Helmy, "Studies on the Pigments of Some Citrus, Prune and Cucurbit Seed Oils when Processed with or without Cottonseed Oil," Journal of American
Oil Chemist's Society, Vol. 67, No. 6, 1990, pp. 376-380.

[6] B. S. Kamel and Y. Kakuda, "Characterization of the Seed Oil and Meal From Apricot, Cherry, Nectarine, Peach and Plum," Journal of American Oil Chemist's Society, Vol. 69, No. 5, 1992, pp. 492-494.

[7] AOAC, "Official Methods of Analysis. Association of Official Chemistry," 14th Edition, Association of Official Analytical Chemists, Arlington, 1994.

[8] F. Demir and M. Özcan, "Chemical and Technological Properties of Rose (Rose canina L.) Fruits Grown Wild in Turkey," Journal of Food Engineering, Vol. 47, No. 4, 2001, pp. 333-336.

[9] Y. Hış1l, "Instrumental Analysis Techniques," Ege Univ. Eng. Fac. Publ. No. 55, Bornova-İzmir, 1998. (in Turkish)

[10] AOAC, "Official Methods and Recommended Practices," Vol. 1, 4th Edition, American Oil Chemists Society, Champaign II, 1990.

[11] S. Skujins, "Handbook for ICP-AES (Varian-Vista). A short Guide to Vista Series. ICP-AES Operation. VarianInt," AG. Zug., Version 1.0, 1998.

[12] H. Püskülcü and F. İkiz, "Introduction Statistic (İstatistiğe Giriş)," Bilgehan Press, Bornova-İzmir, 1989. (in Turkish)

[13] M. F. Mehran, "Characteristics of Iranian Almond Nuts and Oils," Journal of American Oil Chemist's Society, Vol. 51, 1974, pp. 433-434.

[14] N. Kappor, K. L. Bedi and A. K. Bhatia, "Chemical Composition of Different Varieties of Apricot and their Kernels Grown in Ladakh Region," Journal of Food Science and Technology, Vol. 24, No. 2, 1987, pp. 141-143.

[15] M. Özcan, "Composition of Some Apricot (Prunus armeniaca) Kernels Grown in Turkey," Acta Alimenteria, Vol. 29, No. 3, 2000, pp. 289-293.

[16] B. Kacar, "Bitki Besleme (Plant Feeding)," Ankara University Agriculture Faculty Publication No. 367, Ankara, 1977.

[17] B. Matthaus and M. M. Özcan, "Fatty Acids and Tocopherol Contents of Some Prunus spp. Kernel Oils," Journal of Food Lipids, Vol. 16, No. 2, 2009, pp. 187-199.

[18] M. Colombini, M. C. Vanoni and G. Amelotti, "Olio di Noci Nocciole Mandorle Avocado: Composizione Sterolica," La Rivista Delle Sos-Tanze Grasse, Vol. LVI, 1979, pp. 392-393.

[19] L. Zwarts, G. P. Savage and B. L. McNeil, "Fatty Acid Content of New Zealand-Grown Walnuts (Juglans regia L.)," International Journal of Food Science and Nutrition, Vol. 50, No. 3, 1999, pp. 189-194.

[20] S. S. H. Allam, "Utilization of Some Untraditional Sources of High Oleic Acid Oils for Improving Vegetable Oils Stability," La Rivista delle Sos-Tanze Grasse, Vol. LXXVIII, 2001, pp. 337-341.

[21] S. O. Yücel, "Determination of Conjugated Linolenic Acid Content of Selected Oil Seeds Grown in Turkey," 
Journal of America Oil Chemist's Society, Vol. 82, No. 12, 2005, pp. 893-897.

[22] V. I. Deineka, N. G. Gabruk, L. A. Deineka and L. A. Manokhina, "Triglyceride Composition of Oil from Stones of Nine Rosaceae Plants," Chemistry of Natural Compounds, Vol. 38, No. 5, 2002, pp. 410-412.

[23] R. Macrae, R. K. Robinson and M. J. Sadler, "Encyclopaedia of Food Science," Food Technology and Nutrition, Academic Press INC, San Diego, Vol. 5. 1993, pp. 3126-3131.
[24] M. M. Özcan, A. Ünver, T. Uçar and D. Arslan, "Mineral Content of Some Herbs and Herbal Teas by Infusion and Decoction," Food Chemistry, Vol. 106, No. 3, 2008, pp. 1120-1127.

[25] T. Brody, "Nutritional Biochemistry," Academic Press, San Diego, 1994.

[26] F. Saura-Calixto and J. Canellas, "Correlations between Lipid and Protein Contents in Nuts and Oil Seeds," Anal Bromatology, Vol. 34, 1982, pp. 23-31. 